\title{
銅ータンパク質複合体に関する研究
}

\author{
梶 本 五 郎・吉 田 弘 美 \\ 神戸学院大学栄養学部（神戸市垂水区伊川谷町有瀬）
}

\section{Studies on the Copper-Protein Complex}

\author{
Gorō Kajimoto and Hiromi Yoshida \\ College of Nutrition, University of Kobe Gakuin (Arise, Ikawadani, Tarumi-ku, Kobe)
}

\begin{abstract}
The authors observed that in the case of frying, especially whale meat, the frying-oil was colored and deteriorated by substances cozed out from the whale meat, for instance, by nitrogen compounds (protein, pyrrole substance) and metals (iron and copper, etc.) due to the decomposition of blood, etc. and whale oil. Also, the copper and iron in these frying oil were very often observed to be decreased during the storage.

In this paper, for making clear the reason of decrease of copper and iron in frying oil, a model test on the reaction between protein and copper in the system of aqueous solution and oil was carried out. Thus the copper of different stages in the concentration was mixed with casein in water, or, mixture of casein, copper (copper sulfate) and soybean oil was heated for 1 hour at $180^{\circ} \mathrm{C}$, and the amount of aduct formed with these materials was measured.
\end{abstract}

The results obtained were as follows:

It was confirmed that the amount of copper adduct to casein increased with the storage days in both system of aqueous solution and oil, namely, it became clear the easy formation of copperprotein complex.

\section{1 緒}

\section{言}

フライ油の変質は加熱以外に揚げ物よりの無機質，窒 素化合物 ${ }^{1)}$ おび油脂 (たとえば鯨肉揚げで鯨油) ${ }^{2), 3) な ~}$ どがフライ油へ移行し，これらの移行物はフライ油の変

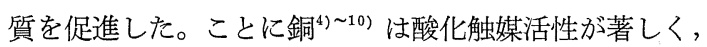
したがって, 油脂の変質上大きな問題であった。ところ で，鯨，魚介肉を揚げたフライ油をフライなべ(鉄製) のまま，あるいはびんに移し貯蔵したものを経時的に取 り出し，口過した油脂について $\mathrm{Cu}$ および $\mathrm{Fe}$ を測定 すると, フライなべ貯蔵のものは Fe は増加するが, $\mathrm{Cu}$ は減少し, びん貯蔵は Fe および Fe いずれも減少 することをしばしば経験してきた。鉄なべ貯蔵による油 脂中の $\mathrm{Cu}$ の増加は, 油脂中の遊離脂肪酸が鉄なべ中の $\mathrm{Fe}$ を溶出させることに起因することがわかったが`， $\mathrm{Cu}$ の減少, さらにびん貯蔵では, $\mathrm{Cu}$ および· Fe の減 少理由については不明であった。その減少理由として油 脂中の他成分（移行物）と反応することが推察される。 そこで，減少原因を検討しようと考えた。 $\mathrm{Cu}$ と他成分 との反応については, ミルク中で $\mathrm{Cu}$ とタンパク質が付 加することが認められて㧍り ${ }^{10), 11)}$, Samuelsson ${ }^{12)}$ はミ
ルク中に添加した $\mathrm{Cu}$ は,その $90 \%$ がミルク中のタン パク質と結合したと報告している。フライ油については 検討されていない。

そこで,フライ油中の $\mathrm{Cu}$ が揚げ物より移行してきた 窒素化合物と付加するかを検討するため, $\mathrm{Cu}$ とカゼイ ンとの付加反応についてモデル実験を行なった。その 結果, $\mathrm{Cu}$ とカゼインは水溶液および油脂中でも容易に 複合体を形成することを認めたので，それらの結果を報 告する。

\section{2 実験}

\section{$2 \cdot 1$ 試料およびその調製}

\section{$2 \cdot 1 \cdot 1$ 油 脂}

合成酸化防止剂を含まない大豆油を用いた。その性状 は過酸化物価 $2.0 \mathrm{meq} / \mathrm{kg}$, 酸価 0.05 , カルボニル価 8.6，ヨウ素価 131.4，ケン化価 189.5 で， $\mathrm{Cu}$ 打よび $\mathrm{Fe}$ はそれぞれ $0.1 \mathrm{ppm}, 1.4 \mathrm{ppm}$ 含有されていた。 なお $\mathrm{Cu}$ の定量法は後述するが, 原子吸光分析法と Borchardt ${ }^{13)}$ らの方法, Fe は 0 ーフェナントロリン比 色法で求めた。

$$
2 \cdot 1 \cdot 2 \text { 鯨 肉 }
$$


油脂含有量 $3.0 \%$ の市販冷凍赤鯨肉を用いた。なお， 油脂量は解凍後, 鯨肉を細断し, ソックスレーを用い, エチルエーテルで $20 \mathrm{hr}$ 抽出後, エチルエーテルを減圧 除去, 残分を油脂として生鯨肉に対する百分率で表わし た。

$2 \cdot 1 \cdot 3$ 銅

特級硫酸銅を選び，蒸留水で再結晶させたものを $\mathrm{Cu}$ 濃度として $2,1,0.2$ および $0.04 \mathrm{ppm} / \mathrm{ml}$ になるよう 再蒸留水 $(\mathrm{pH}$ 6.95) に溶解し調製した。

$2 \cdot 1 \cdot 4$ 力ゼイン

市販乳製カゼインを選び，エチルエーテルで $10 \mathrm{hr}$ 抽 出後，20 mesh のふるいを通したものを用いた。な お,カゼイン中には $\mathrm{Cu}$ はほとんど含有されていなかっ た。

\section{$2 \cdot 2$ 実験方法}

\section{$2 \cdot 2 \cdot 1$ 揚 げ 方}

$2 l$ 容鉄なべ中に大豆油 $500 \mathrm{~g}$ を入れ, 室内に $2 \mathrm{hr}$ 放置し解凍させた触肉を $5 \times 1.3 \mathrm{~cm}$, 厚さ $1.3 \mathrm{~cm}$, 重さ

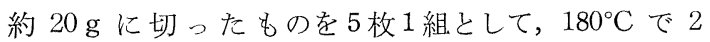
min 揚げ, その後同操作を繰り返し, 鯨肉量が 500 , $1000 ， 1500$ および $2000 \mathrm{~g}$ ごとにフライ油をヒョウ取 し,フライ油中の $\mathrm{Cu}$ および $\mathrm{Fe}$ と窒素量を測定した。 同様, 加熱のみの対照実験を併行した。なお；解肉揚げ 量が $500 \mathrm{~g}$ 目をフライ回数 1 回目, 以下 $500 \mathrm{~g}$ 増すご とに 2〜4 回目と呼んだ。 $\mathrm{Cu}, \mathrm{Fe}$ および窒素量測定時 のフライ油は, いずれも $3 \mathrm{G} 3$ ガラスロ過器でロ過した ものを用いた。

\section{$2 \cdot 2 \cdot 2$ フライ油の貯蔵}

$2 \cdot 2 \cdot 1$ の方法で鯨肉 $2 \mathrm{~kg}$ を揚げ, 得られたフライ油 を，(1)フライなべのまま放置，(2)フライ油をカッ色びん に移し貯蔵した。(1)，(2)それぞれの貯蔵フライ油を経時 的に取り出し，口過したフライ油について $\mathrm{Cu}$ と $\mathrm{Fe}$ を求めた。

\subsection{3 $\mathrm{Cu}$ および $\mathrm{Fe}$ の定量}

予備実験では, フライ油中の $\mathrm{Cu}$ が微量のためか, 従 来の比色定量法では誤差を生じやすかったので原子吸光 分析法を用い, $\mathrm{Cu}$-タンパク複合体中の $\mathrm{Cu}$ 量は, 添加 モデル実験を行なったため比較的 $\mathrm{Cu}$ 量が多いこと と，燃焼が容易なこと，扝よび一度に数多く測定する場 合，比色法が便利で，かつ，ほとんど䛊差がみられなか ったので，比色定量法を用いた。

\section{$2 \cdot 2 \cdot 3 \cdot 1$ 原子吸光分析法}

日本ジャーレル・アッシュ社製の原子吸光分析装置 AA-1 型を使用し，試料油 $30 \mathrm{~g}$ を白金蒸発ザラにとり， 電気炉内で灰化, 残分を $\mathrm{HCl}(1: 1) 30 \mathrm{ml}$ で溶解, 再 蒸留水を加え $100 \mathrm{~m} l$ としたものを下記の条件で測定し た。

\section{$2 \cdot 2 \cdot 3 \cdot 2 \mathrm{Cu}$ の比色定量法 ${ }^{13)}$}

\begin{tabular}{l|c|c}
\hline \multicolumn{1}{c|}{ Metals } & $\mathrm{Cu}$ & $\mathrm{Fe}$ \\
\hline Model & $\mathrm{A} \mathrm{A}-1$ & $\mathrm{~A} \mathrm{~A}-1$ \\
Source & $3247 \AA$ & $2483 \AA$ \\
Grating & $3000 \AA$ & $3000 \AA$ \\
$\mathrm{PM}$ & $\mathrm{R} 106$ & $\mathrm{R} 106$ \\
Damping & 4 & 3 \\
Burner slit & $10 \mathrm{~cm}$ & $10 \mathrm{~cm}$ \\
Fuel & $\mathrm{C}_{2} \mathrm{H}_{2}, 2 l / \mathrm{min}$ & $\mathrm{C}_{2} \mathrm{H}_{2}, 2 l / \mathrm{min}$ \\
Current & $10 \mathrm{~mA}$ & $10 \mathrm{~mA}$ \\
Blaze slit & $100 \mu, 150 \mu$ & $100 \mu, 150 \mu$ \\
Chart speed & $40 \mathrm{~mm} / \mathrm{min}$ & $40 \mathrm{~mm} / \mathrm{min}$ \\
Sens & 90 & 80 \\
Oxidant air & $8 l / \mathrm{min}$ & $8 l / \mathrm{min}$ \\
\hline
\end{tabular}

$\mathrm{Cu}$-タンパク質複合体を灰化後, 下記の検量線作成時 々同様の方法で 発色させ， 日立分光光電光度計 124 型 を用い, $425 \mathrm{~m} \mu$ の吸光度を測定し，検量線と比較し求 めた。なお，同時に空試験を行なった。

(1) 検量線の作成

精製した硫酸銅 $0.1965 \mathrm{~g}$ を再蒸留水で溶解し, $500 \mathrm{~m} l$ とし，この溶液 $10 \mathrm{~m} l$ を $1 l$ 亿希釈し標準溶液とした $(\mathrm{Cu}$ として $1 \mathrm{~m} l$ 中に $1 \mathrm{ppm}) 。 こ の$ 標準溶液から 5 , 10,15 および $20 \mathrm{~m} l$ を $100 \mathrm{~m} l$ メスフラスコにとり, $2 \mathrm{~N}-\mathrm{HCl} 80 \mathrm{~m} l$ を加え蒸留水で標線まで希䣋する。こ れよりそれぞれ $50 \mathrm{~m} l$ を $100 \mathrm{~m} l$ メスフラスコにとり， エチレンジアミン四酶酸二ナトリウム溶液 $(50 \mathrm{~g}$ を蒸 留水で $1 l$ とする) $20 \mathrm{~m} l$ を加え, アンモニア水で $\mathrm{pH}$ $9.0 \sim 9.2$ になるよう調製し, 蒸留水で標線まで希釈し た。これを $100 \mathrm{~m} l$ 分液漏斗に移し, さらに $10 \mathrm{~m} l$ の 蒸留水でメスフラスコ中を洗浄し, 洗液は分液漏斗に加 える。これにジェチルアンモニウム・ジェチルジチオカ ルバメート試薬 (東京化成工業特級試薬, $10 \mathrm{~g}$ をク口 ロホルムに溶解し $1 l$ とする) $5 \mathrm{~m} l$ を加え， $5 \mathrm{~min}$ 激 しく振とらした後, 無水硫酸ナトリウ ムを詰めたガラス 口過器で吸引口 過, クロロホルム 溶液は吸光度測定 用 $1 \mathrm{~cm}$ ガラスセ ルに移し, $10 \mathrm{~min}$ 後, $425 \mathrm{~m} / 6$ ○吸 光度を測定した。 検量線は Fig.-1 のと拈りである。

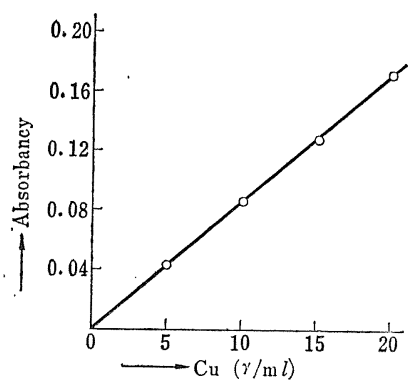

Fig.-1 Calculation curve of copper.

\section{$2 \cdot 2 \cdot 3 \cdot 3$ 窒 素 量 \\ ケルダール法によった。}

$2 \cdot 2 \cdot 4 \mathrm{Cu}$ 一カゼイン複合体の調製とその分別法

$\mathrm{Cu}$ とカゼインの付加有無を検討するため, モデル実 験を行なった。 


\section{$2 \cdot 2 \cdot 4 \cdot 1$ 水溶液中での反応}

$\mathrm{Cu}$ 濃度の異なる水溶液をそれぞれ $50 \mathrm{~m} l$ ずつ用い， $1 \mathrm{~g}$ 精七ョウしたカゼインと混合, ときどき振とうしな がら常温で放置した。経時的に試料を取り出し，3G3 ガラスロ過器で吸引口過, 再蒸留水で残分を充分洗浄 し, 遊離の $\mathrm{Cu}$ を除去した。残分を $40^{\circ} \mathrm{C}$ で減圧乾燥 後, 一定量を灰化させ, $2 \cdot 2 \cdot 3 \cdot 2$ の比色法で $\mathrm{Cu}$ を定量 した。洗浄水についても一定量にした中から $\mathrm{Cu}$ 量に応 じ適宜ヒョウ取し $\mathrm{Cu}$ 量を求めた。また, 対照に $\mathrm{Cu}$ を含まない水溶液にカゼインを浸セキし，同操作を行な いカゼイン中の $\mathrm{Cu}$ を求めた。

な㧍, 反応液中の $\mathrm{Cu}$ 量が経時日数の経過とともに減 少し,カゼインの方に $\mathrm{Cu}$ 量が増加することから, $\mathrm{Cu}$ が カゼインに付加し, 複合体を形成したものと考光, 便宜 上, $\mathrm{Cu}$-タンパク質複合体と称し取り扱った。

\section{$2 \cdot 2 \cdot 4 \cdot 2$ 油脂中での反応}

$100 \mathrm{~m} l$ 容試験管に大豆油 $10 \mathrm{~g}$ をとり, カゼイン 200 $\mathrm{mg}$ と $\mathrm{Cu}$ として $1 \mathrm{ppm}(10 \mathrm{ppm} / \mathrm{m} l$ のものを使用 $)$ になるよう $0.1 \mathrm{~m} l$ の硫酸銅溶液を添加し，かくはんし ながら $180^{\circ} \mathrm{C}$ で $1 \mathrm{hr}$ 加熱した。加熱直後のものと放置 したものを経時的に取り出し, エチルエーテルを加え,

$3 \mathrm{G} 3$ のガラスロ過器で吸引口過, 油脂がなくなるま でエチルエーテルで洗浄, 続いて水洗を行ない, 上記同 様, 残分中の $\mathrm{Cu}$ 量を求めた。なお，油脂使用時に加熱 したのは, できるだけ揚げ物時の条件にあわすために行 なった。

\section{3 実 験 結 果}

\section{1 鯨肉揚げとフライ油中の無機質および窒素量}

揚げ物とフライ油中の無機質および窒素量 ${ }^{11}$ について はすでに報告したが，今回，そのフライ油の貯蔵と $\mathrm{Cu}$
および $\mathrm{Fe}$ 量の変化を検討するため, ‘ず，鯨肉を揚 げ，その揚げの回数とフライ油中の無機質および窒素量 を求めた。結果は, Fig.-2〜3 のと抢りである。

鯨肉の揚げ物量が多くなるにしたがい，フライ油中に は無機質および窒素量がいずれもわずかずつ増加した。 おそらく，鯨肉よりフライ油へ移行してきたものと考え られる。

\section{$3 \cdot 2$ フライ油の貯蔵と $\mathrm{Fe}$ および $\mathrm{Cu}$ 量の变化}

揚げ物よりフライ油へ移行した $\mathrm{Fe}$ および $\mathrm{Cu}$ が無 機の形 (遊離金属) なのか, 塩 (脂肪酸および他成分と の結合) なのか，その存在形態あるいは貯蔵中の変化な どについても不明確である。そこで, 鯨肉揚げ後のフラ イ油をフライなべのままおよびびんに移し,。経時日数と 油脂中の $\mathrm{Cu}$ および $\mathrm{Fe}$ について検討した。結果は,

Fig.-4のと㧍りである。

びん貯蔵のフライ油は, 経時日数の経過とともに $\mathrm{Cu}$ および Fe はいずれも減少した。フライない゙貯蔵のもの は $\mathrm{Cu}$ は減少したが，Fe はほとんど減少せず，むしろ わずかながら増加の傾向にあった。 Fe の増加傾向は， 先に報告 ${ }^{1)}$ したらに, フライ油中の遊離酸が容器中の 鉄を溶出した結果と考えられ，Fig.-2 の対照油でもわ ずかずつの Fe の増加が認められ，逆にびん貯蔵では増 加がみられないことからでも明らかである。Cuの減少 については, 口過したガラス口過器上の残分の方に $\mathrm{Cu}$ 量が増加することから，これらの成分とフライ油中の $\mathrm{Cu}$ 预よび $\mathrm{Fe}$ などが反応し複合体を形成するのでは ないかと考えられる。残分について定性試験を行ならと 窒素があり，かつビュレット反応が陽性であった。した がって，Fig.-2 にみられるようにフライ油に窒素量が 増加していることと考光わせ, 鯨肉からフライ油へ移 行してきた窒素化合物（タンパク質など）と Cu および

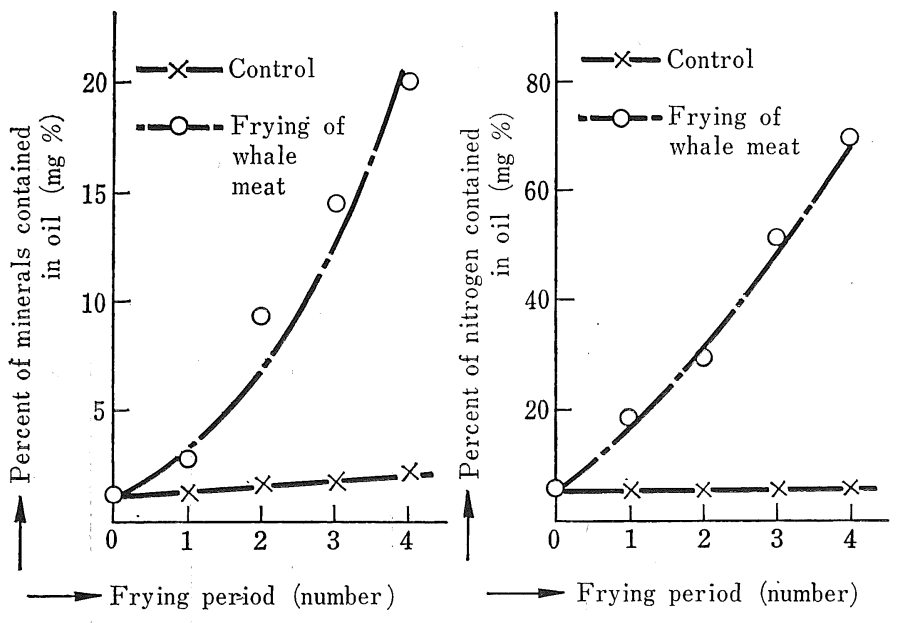

Fig.-2 Relationship between the minerals contained and nitrogen in frying oil and frying of whale meat.

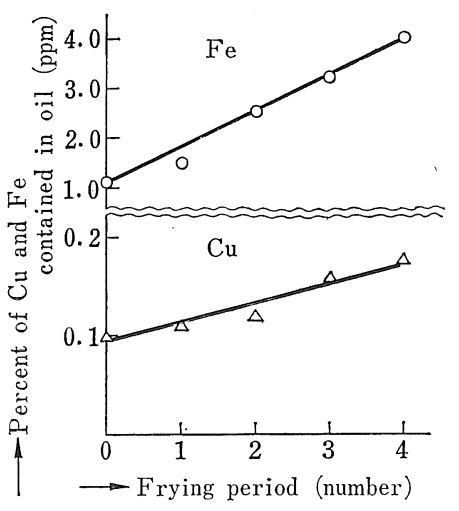

Fig.-3 Relationship between the iron and copper in frying oil and frying of whale meat. 


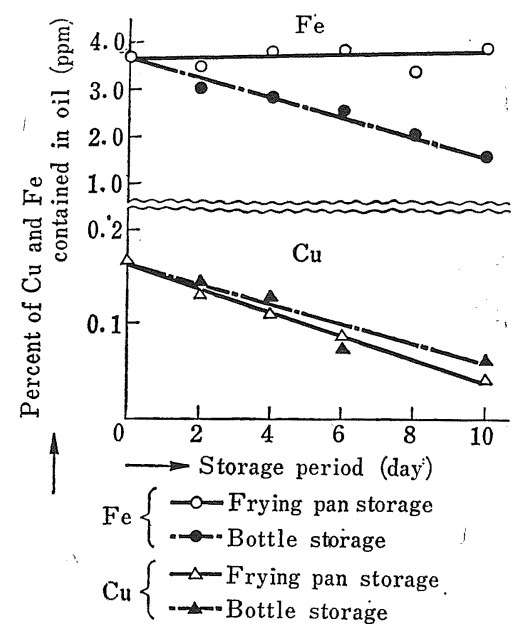

Fig.-4 Changes of iron and copper in frying oil and storage days.

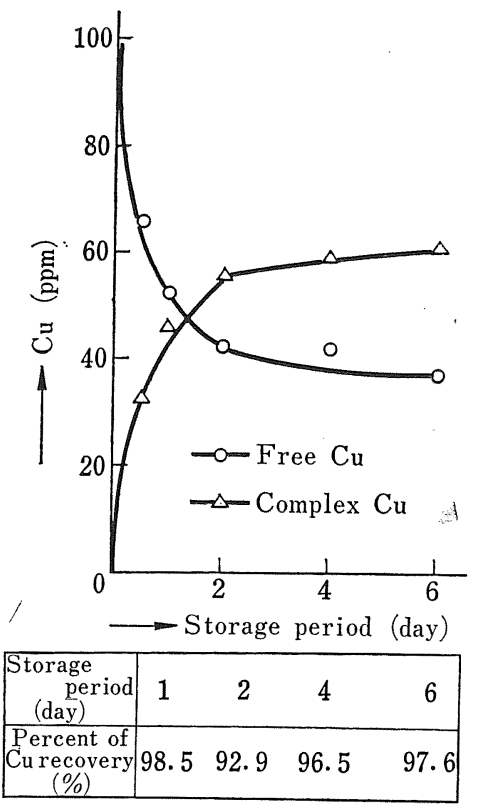

Fig.-5 Reactions between copper and protein.

$\mathrm{Fe}$ が容易に複合体を形成するものと推察される。そこ で，その点を確かめるため，酸化触媒活性の高い $\mathrm{Cu}$ と タンパク質について複合体形成有無のモデル実験を行な った。

\section{3·3 Cu-カゼイン複合体の形成について}

$\mathrm{Cu}$ とカゼインの反忘について水溶液系と油脂系とに ついて検討した。

$3 \cdot 3 \cdot 1$ 水溶液中での反応

$50 \mathrm{~m} l$ の硫酸銅溶液 (Cu として $100 \mathrm{ppm}$ ) とカゼイ ンを混合し，経時的に試料を取り出し，2・2・4・1 の方法

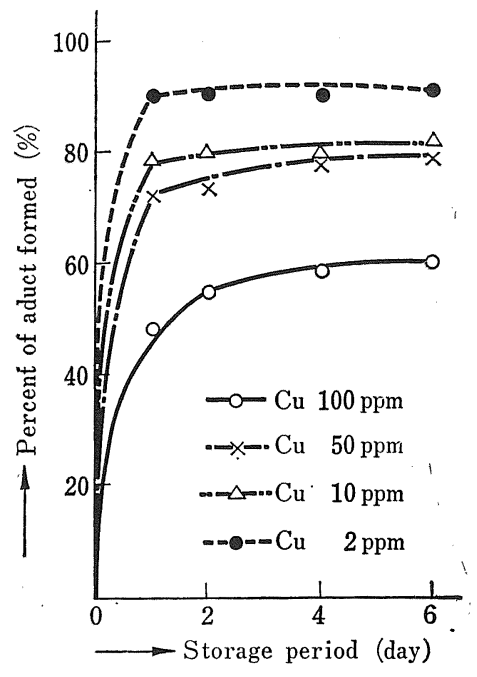

Fig.-6 Relationship between percent of aduct formation and different stages of copper quantity.

で分別, その分別カゼインと口過液について $\mathrm{Cu}$ 量を 求めた。結果は, Fig.-5 のとおりである。

ついで, $\mathrm{Cu}$ 濃度の異なる溶液（Cu として $2,1,0.2$ および $0.04 \mathrm{ppm} / \mathrm{m} l) 50 \mathrm{~m} l$ とカゼインを混合し，経 時日数と分別カゼイン中の $\mathrm{Cu}$ 量を求め, $\mathrm{Cu}$ の付加率 を算出した。結果は，Fig.-6 のとおりである。

なお, 付加率の求め方は, それぞれ使用した $\mathrm{Cu}$ 量を 基準とし，カゼイン中の $\mathrm{Cu}$ 量を求め,その割合を百分 率として表わした。

Fig.-5に示すように, 経時日数の経過とともに口液 中の $\mathrm{Cu}$ 量 (free $\mathrm{Cu}$ ) が減少し，カゼイン中に $\mathrm{Cu}$ (complex $\mathrm{Cu}$ ) が増加した。なお， $\mathrm{Cu}$ の回収率 (free $\mathrm{Cu}$ と complex $\mathrm{Cu})$ は，各回とも $95 \pm 2 \%$ であった。 したがって, 同法による $\mathrm{Cu}$ の定量㐨よび $\mathrm{Cu}$-カゼイ ン複合体の分別法が可能であると考えた。Cu とカゼイ ンは水溶液中で容易に複合体を形成することがわかっ た。 $\mathrm{Cu}$-カゼイン複合体の 形成能は, $\mathrm{Cu}$ 濃度の低いも のほど付加率が高い。なお，Fig.-6 の実験時も $\mathrm{Cu}$ の 回収率は $97 \pm 1 \%$ であった。

Table-1 Relationship between percent of aduct formation and quantity of casein.

\begin{tabular}{c|c|c|c|c|c|c}
\hline Casein & $\mathrm{Cu}$ & \multicolumn{2}{|c|}{$\begin{array}{c}\text { Copper-protein } \\
\text { complex }\end{array}$} & \multicolumn{2}{|c|}{$\begin{array}{r}\text { Residual } \\
\text { copper }\end{array}$} & Percent \\
\cline { 3 - 6 } (g) & $(\mathrm{ppm})$ & $\begin{array}{c}\text { Volume } \\
\text { of } \mathrm{Cu} \\
(\mathrm{ppm})\end{array}$ & $\begin{array}{c}\text { Percent } \\
\text { of aduct } \\
\text { formed } \\
(\%)\end{array}$ & $\begin{array}{c}\text { Volume } \\
\text { of } \mathrm{Cu} \\
(\mathrm{ppm})\end{array}$ & $\begin{array}{c}\text { Percent } \\
\text { of non- } \\
\text { aduct } \\
\text { formed } \\
(\%)\end{array}$ & recovery \\
\hline 0.5 & 50 & 35.4 & 70.8 & 13.2 & 26.4 & 97.3 \\
1.0 & 50 & 36.8 & 73.6 & 12.0 & 24.0 & 97.6 \\
2.0 & 50 & 33.8 & 67.6 & 14.0 & 28.0 & 95.6 \\
\hline
\end{tabular}


ついで, $\mathrm{Cu}$ 濃度を一定 $(50 \mathrm{ppm} / 50 \mathrm{ml})$ とし, カゼ イン量を $0.5,1.0$ および $2.0 \mathrm{~g}$ とかえた場合の $\mathrm{Cu}$ タンパク質複合体形成量について検討した。結果は,

Table-1 のとおりである。なお，放置日数は 1 日であ る。

カゼイン量の多少にかかわらず， $\mathrm{Cu}$ ータンパク質複合 体形成量にはほとんど差がみられなかった。したがっ て，Cu と反応するのに必要なカゼイン量があればよい ものと思われる。

\section{$3 \cdot 3 \cdot 2$ 油脂中での反応}

水溶液中では $\mathrm{Cu}$ とカゼインが容易に複合体を形成 することを認めた。油脂中でも同様, 複合体を形成する かを検討した。油脂中での反応条件は，Fig.-4 に示し たように, 貯蔵に伴ないフライ油中の $\mathrm{Cu}$ が減少して おり, その理由をあわせ考察するため, 大豆油 $10 \mathrm{~g}$ に $1 \mathrm{ppm}$ の $\mathrm{Cu}$ とカゼイン $1 \mathrm{~g}$ を良く混合し，ただちに $180^{\circ} \mathrm{C}$ で $1 \mathrm{hr}$ 加熱した。なお, 大豆油中に $0.1 \mathrm{ppm}$ の $\mathrm{Cu}$ が既存しているので， $\mathrm{Cu}$ 量はその相加量とな る。対照にカゼインのみを加え同様, $1 \mathrm{hr}$ 加熱後, 経 時日数と $\mathrm{Cu}$ 量の変化を調べた。結果は, Fig.-7 のと おりである。

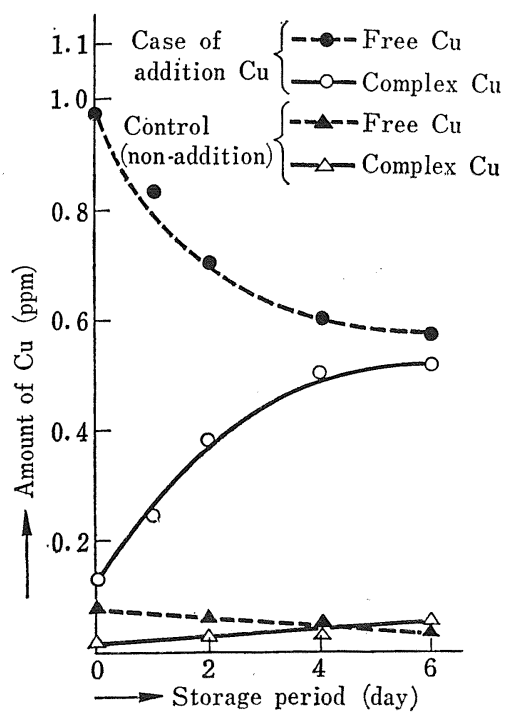

Fig.-7 Reactions between copper and protein in oil.

放置開始時にすでに対照カゼインで約 7\%, 添加した $\mathrm{Cu}$ の場合は, $10 \%$ 程度の $\mathrm{Cu}$ がカゼインに付加して いた。おそらく加熱操作中に付加したのであろう。放置 日数の経過とともに対照カゼインでも $\mathrm{Cu}$ 量が増加し た。それは大豆油に既存の $\mathrm{Cu}$ と複合体を形成したも の乞思われる。添加した Cu の場合も放置日数の経過 とともに遊離の $\mathrm{Cu}$ が減少し, カゼインに $\mathrm{Cu}$ が増加

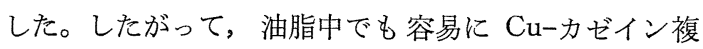

合体を形成するといえる。このことから Fig.-4 の鿷肉 を揚げたフライ油中の $\mathrm{Cu}$ の減少は, 鯨肉より移行し てきた窒素化合物おそらくタンパク質と複合体を形成し た結果と考察される。

一方, タンパク面からみた場合, 油脂に添加したカゼ インあるいは鯨肉よりフライ油へ移行してきたタンパク 質は, 加熱により変性あるいは分解などが起こっている ものと考えられ，Cu との反応は熱変性タンパク質が主 体をなすものと思われる。フライ油中のタンパク質につ いては遂次検討していく。

\section{4 考察}

揚げ鯨肉よりフライ油へ移行した $\mathrm{Cu}, \mathrm{Fe}$ などの存 在形態については金属イオンあるいは脂肪酸塩の形態が 考えられるが，それぞれの分別法と割合については今回 検討しなかった。もし，二つの金属の存在形態があると すれば，その割合はフライ油の変質度（遊離脂肪酸量） によって相違するであろうし，タンパク質との付加反応 も金属イオンおよび塩のいずれの形で付加するかを検討 する必要がある。

フライ油中の窒素量は揚げ物の種類によって異なり， ジヤガイモ执よびピーマンなどは, 鯨, 魚肉揚げに比べ 非常に少なく, また, 貯蔵フライ油脂中の $\mathrm{Cu}, \mathrm{Fe}$ の減 少割合も鯨肉揚げのフライ油に比べ少ないことを確かめ た。したがって，窒素量と $\mathrm{Cu}, \mathrm{Fe}$ の減少との間には 一定の比例関係が考えられ，窒素化合物が付加の主体で あることは事実のようである。ところで，フライ油中の 窒素化合物については, フライ油に溶解分散（ガラスロ 過器を通過したもの）しているものと, 鯨, 魚肉からは ずれた微細粒子がフライ油に浮遊している形（ガラスロ 過器上に残留) とが考えられ，そのいずれの形のものと 付加しやすいかは, 口過フライ油では $\mathrm{Cu}, \mathrm{Fe}$ が減少 し, 残留物の方に $\mathrm{Cu}, \mathrm{Fe}$ が増加することから, 浮遊 しているタンパク粒子の方が金属との反応に至大な関係 を有するのではないかと思われる。もちろんこれに関連 し，金属との結合形態あるいは $\mathrm{Cu}$ タンパク質複合体 の分別法の適否が問題になることはいうまでもない。油 脂に溶けている窒素化合物と金属との結合物, あるいは 脂肪酸塩ではガラスロ過器を通過してしまうだろうし， これらの結合物は現行法では確認できず見落としてしま う。しかし，本実験からしてロ過フライ油ではかなり多 量の $\mathrm{Cu}$ および $\mathrm{Fe}$ が減少することから, 油脂に溶けて いる窒素化合物あるいは脂肪酸と $\mathrm{Cu}, \mathrm{Fe}$ の形成能よ り，浮遊しているタンパク質との反応の方が大きいもの と思われる。

フライ油中の $\mathrm{Cu}$-タンパク質複合体の分別法として, 著者らの行なった方法は, 油脂分をエチルエーテルで完 全に除き,ついで蒸留水で遊離の $\mathrm{Cu}$ を洗浄した。遊離 
の $\mathrm{Cu}$ 除去したのにもかかわらず,なおかつ残留タン パク質に $\mathrm{Cu}$ があり，経時日数の経過 とともに増加す ることから，Cu-タンパク質複合体が形成され，また， その分別法が可能であると考えた。 $\mathrm{Cu}$-タンパク質複合 体の形成機構は物理的結合か，イオン結合なのかについ ては不明である。中島ら ${ }^{14}$ は, チーズカゼインの $\mathrm{Ca}^{++}$ 結合力を山内ら ${ }^{15}$ の方法で測定していることから， $\mathrm{Cu}$, Fe とカゼインの結合は，イオン結合が主体であると推 測される。

水溶液中のカゼインは放置日数が長くなるにしたが い, カゼインの腐敗変性の可能性が考えられ, また, フ ライ油中のタンパク質は熱変性が当然起こっているもの と思われる。したがって, フライ油脂中では熱変性タン パク質と $\mathrm{Cu}$ の付加反応ともいえる。ところで,タンパ ク質変性の有無扝よび変性度合と $\mathrm{Cu}$ との付加率, ある いはタンパク質の熱変性がさらに進んで分解した物と $\mathrm{Cu}$ との付加有無については検討しなかった。今後, フ ライ油中のタンパク質の形態と金属との付加反応, さら に金属の種類とタンパク質との付加速度, 複合体形成量 などについて検討したい。(昭和 46 年 6 月 2 日受理)

\section{文献}

1) 梶本, 栄養と食糧, 15, 221 (1962)

2) 梶本, 吉田, 栄養と食糧, 23, 255 (1970)

3) 梶本, 吉田, 栄養と食糧, 23, 443 (1970)

4) H.T. Spannuth, J. Am. Oil Chemists' Soc., 26, 618 (1949)

5) C.D. Evans et al., J. Am. Oil Chemists' Soc., 29, 61 (1952); ibid, 28, 68 (1951)

6) N.M. Emanuel, T.N. Lyaskovskaya "The Inhibition of Fat Oxidation", p. 79 (1967), Pergamon

7) A.E. King et al., Oil \& Soap, 10, 204 (1933)

8) J.C. Cowan "Autoxidation and Antioxidants," 2, 593 (1962), Interscience; J. Am. Oil Chemists' Soc., 43, 300 A (1966)

9) A.L. Tappel, Food Res., 18, 560 (1953)

10) A.L. Tappel, J. Am. Oil Chemists' Soc., 32, 252 (1955)

11） A. Patron, 第 9 回油脂国際会議講演要旨 (1968)

12) E.G. Samuelsson, Milchwissenshaft, 21, 335 (1966)

13) L.G. Borchardt, J.P. Butler, Anal. Chem., 29, 414 (1957)

14）中島ら, 日本農芸化学会全国大会講演 (1971)

15) 山内ら, Agr. Biol. Chem., 31, 54 (1967)

\title{
EDTA 滴定法による洗剤中の炭酸ナトリウムの分析
}

\author{
永井敏 雄・二本木恒夫 \\ ライオン油脂株式会社研究部 (東京都江戸川区平井 3-2,397)
}

\section{Determination of Sodium Carbonate in Household Detergents by the Method of EDTA Titration}

\author{
Toshio Nagai and Tsuneo Nihongi \\ Research Laboratory, Lion Fat and Oil Co. (Hirai Edogawa-ku, Tokyo)
}

Ordinarily, Schloetter's method is usual for the determination of sodium carbonate to be detected about $1 \sim 6 \mathrm{wt} \%$ in the household detergents.

However, its analytical preciseness is not enough satisfactory.

A determination of sodium carbonate in household detergents has been developed, in which sodium carbonate is absorbed in barium chloride as carbon dioxide and excess barium is titrated with EDTA.

The carbon dioxide produced by decomposition of the sample using $30 \mathrm{vol} / \mathrm{vol} \%$ sulfuric acid is absorbed in a barium chloride in $0.1 \mathrm{~N}$-sodium hydroxide. The precipitate of barium carbonate is filtrated and the excess of barium ion in the solution is titrated with standard solution of EDTA using Eriochrome Black $\mathrm{T}$ as the indicator and the amount of sodium carbonate is calculated.

The time required for the analysis of sample was about $1 \sim 1.5 \mathrm{hrs}$ with recovery more than 96.9 $\mathrm{wt} \%$ and precision of recovery was $2 \%$ in coefficient of variation.

Furthermore, sodium carbonate in aqueous solution could be detected by the same method. 